\title{
INTERNATIONAL MARKETING IN BUSINESS PRACTICE OF SMALL AND MEDIUM-SIZED ENTERPRISES
}

\section{MEZINÁRODNÍ MARKETING V OBCHODNÍ PRAXI MALÝCH A STř EDNÍCH FIREM}

\section{ING. ZDEN'rK BEDNARLí́K, PH.D., MBA.}

\author{
Katedra marketingu $\mid$ Department of Marketing \\ Obchodn \podnikatelská fakulta v Karviné School of Business Administration in Karvina \\ Slezská univerzita v Opav门 Silesian University in Opava \\ $\bowtie$ Univerzitni nám. 1934/3, 73340 Karviná, Czech Republic \\ E-mail: bednarcik@opf.slu.cz
}

\begin{abstract}
Annotation
The theme of paper apply to problems of regional perspectives, it deal with regional small and medium-sized enterprises (SMEs). These firms appearance to its number have strong impact to development of whole region. The results of research can contribute improvement of marketing management these firms with subsequent positive influence to development of region.This paper examines international marketing in business practice of Czech exporting small and medium-sized enterprises (SMEs) with regard to the strategic perspectives. Research was focused on Czech exporting SMEs from Moravian-Silesia region and their behavior on international markets. For purpose of collecting data, a questionnaire was given to 262 SMEs involved in international business. Statistics utilized in this research included frequency, mean, percentage, and chi-square test. Data were analyzed by Statistical Package for the Social Sciences software. The research analysis disclosed that there is certain space for improvement in strategic marketing especially in a marketing research, perception of cultural and social differences, product adaptation and usage of marketing communication tools.
\end{abstract}

\section{Key words}

international marketing, marketing mix, marketing research, small and medium-sized enterprises (SMEs), strategic marketing

\section{Anotace}

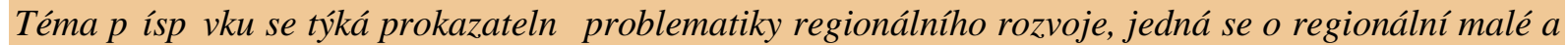
stŚední firmy, které vzhledem k pol etnímu zastoupení v celé podnikatelské sféśe mají výrazný dopad na rozvoj celého regionu. Výsledky výzkumu mohou pŚsisph ke zlepġení marketingového Śizení tḩ̧hto firem s následným pozitivním vlivem na rozvoj regionu. PŚsp円jek zkoumá mezinárodní marketing $v$ obchodní praxi malých a stŚédních firem ve vztahu ke strategickému vývoji. Výzkum byl zam hśen na exportujicí malé a stŚední firmy Moravskoslezského regionu zhlediska jejich p丁sobení na mezinárodních trzích. Pro získání potŚbných informací a odpovゆlí bylo osloveno 262 malých a stŚedních firem, podnikajících v mezinárodním obchod $\mathbf{n}$ Získaná data byla analyzována pŚsisluginými statistickými metodami a programy. Výzkumné analýzy odhalily, ǵe je zde urḷitý prostor pro zlepg்ování v oblasti strategického marketingu, pŚsedevǵ்m v marketingovém výzkumu, ve vnímání kulturních a sociálních odlig̉ností, v adaptaci produkt $\mathrm{\top}$ na podmínky jednotlivých zemí, v úl innosti pouǵ̛vání nástroj丁 marketingového mixu.

\section{Klílová slova}

mezinárodní marketing, marketingový mix, marketingový výzkum, malé a stŚední firmy, strategický marketing 


\section{JEL classification: $E 52$}

\section{Introduction}

SMEs are a driving force of a national and also European economy, employment, social climate and technological advancement. In the Czech Republic, the participation of SMEs in employment in private sector is $70 \%$. SMEs represent $99.9 \%$ of the total number of business entities and generate approximately one third of nominal HDP (Czech statistical office, 2013).

Micro companies (up to 10 employees) make the biggest group of entrepreneurs. They differ mainly because of strong connection with the entrepreneur or a family. These may also be self-employed businessmen. They do not have sufficient workforce to cover specialized activities connected with expansion of their business, gathering information or a market analysis. They are oriented and dependent on their local market. They have problems penetrating foreign markets as they do not have professional and financial capacity.

Small companies are considered to have 10 to 50 employees, which is the basic capital enabling to access opportunities of the European market. Small companies fill peripheral spheres of the market, help faster development of weaker regions through a good knowledge of locality, flexibility and diversity. They act against monopolization, they fortify the competition. Small companiesô interests are oriented locally but they may go beyond borders to the foreign markets.

Lastly, medium-sized enterprises have greater financial research, focusing on new technologies and have a better bargaining position with the banks. With 50 to 250 employees they are capable of creating specialized teams for particular foreign markets. They have the instruments and motivation (in the context of their potential outlets) to expand into other markets.

Unfortunately, many of these enterprises have to deal with apparent difficulties resulting from consequences of still lasting effects of the economic crisis. Moreover, there is decreasing customerô purchasing power all over the regions of the Czech Republic and high competition across all the industries. Therefore, growth of international diversification is an important strategic option for small and medium businesses ( $\mathrm{Lu}$ and Beamish, 2011, Knight, 2001). Which is possible due to the internationalization of companies. Internationalization is broadly accepted term which refers to the process of increasing involvement in international operations (Welch and Luostarinen,1988).

International marketing focuses on satisfying the needs and wishes of customers in foreign markets (Machková, Král, Lhotáková, 2010, Stoklasa, Starzyczna, Matuğnská, 2013). As a business philosophy it offers a great opportunity for SMEs to succeed in high competitive markets. On the other hand, it is much more complex because company faces two or more sets of uncontrollable variables originating from various countries (Onkvisit and Shaw, 2004).

When any company enters a foreign market there is an important strategic decision. There are two main possibilities which are standardization and adaptation that could be executed within product or promotion element of marketing mix (Szymanski, Bharadwaj, Varadarajan, 2003). Another key success factors are price and distribution. Distribution channels within countries vary considerably by size and character (Kotler and Keller, 2012).

Summarizing previous researches in the field, there are few academic papers (Kazem and Heijden,2006, Hynes, 2010, Mason and Pauluzzo, 2009), focusing on both the SMEs and international business since it had been very complicated for a long time for SMEs to enter foreign market. Those days are gone and thanks to development in information and communication technologies, internationalization and globalization of the markets, more SMEs are active on international markets. 


\section{Methods}

The methodical approach was chosen in steps from general to special (induction reasoning). For the research purposes two objectives were defined.

The main aim of this research was to assess the specific behavior of Czech small and medium-sized enterprises operating in the foreign markets. The secondary objective was to determine what strategic actions in the field of international marketing (in terms of selected elements of the marketing mix product, distribution and marketing communication) can strengthen small and medium businesses competitiveness.

The research was carried out during the period from March to May 2013. As a technique of selecting a sample of respondents was used semi-representative technique of choice (non-exhaustive survey), which consists of selecting respondents based on the assumption(judgment) that these respondents meet certain requirements. The selection of respondents was defined according to the criteria of a firm headcount. In order to identify small and medium companies the sample was limited according to the EU methodology as follows: maximum headcount 250, maximum turnover ú50 million or balanced sheet total út3 million. Further, only exporting SMEs were included from Moravian-Silesian region. The reason for choosing the region of Moravia-Silesia was its geographic location as it borders two countries (Slovakia republic and Poland). Another reason was that the university where the research was conducted is located there.

Due to the type of required information and nature of the issue, questioning method was chosen as a research method (personal interviewing technique). For purposes of personal interview we developed questionnaire consisted of 12 questions plus 6 additional identification questions such as number of employees, type of business, exporting products, ratio of exports to total sales, company name, address and contact. Ground rules of intelligibility to respondent (intelligible content, consistency, reasonable length) were followed. Subsequently, students of International marketing course were asked to collect the data. After a profound training, students conducted personal in-office interviews with companiesôrepresentatives. Once students filled up questionnaire, representatives were asked to sign the document to prove authenticity.

\section{Results}

When defining a general sample of respondents the criterion of the size structure of the participating small and medium-sized companies, i.e. the number of employees was used.

Therefore there are three categories:

- Micro-entities, number of employees up to 10.

- Small companies, number of employees up to 50.

- Medium companies, number of employees up to 250.

Sample selection was random. Therefore medium-sized companies are heavily prevailing in the sample. On the other hand, these are typical exporters in the SMEs category [14]. Ratio export to total sales for whole sample is $55 \%$ in average.

Machinery industry $(24,81 \%)$ is the most frequent industry represented in the sample followed by consumer goods sector $(15,65 \%)$ and steel industry $(12,6 \%)$. There are foodstuffs, chemical, electrical, woodworking, construction, textile and clothing and other industries.

For most frequently represented machinery industry are typical these exported products: anchors for ships and drilling platforms, cogwheel, material handling equipment, automation lines, machine parts, sanitary equipment, foundry equipment, plastic production industry, mining equipment, castings, 
cranes, computer assisted machining centers, gear manufacturing tools, alternators, starters, conveyors, elevators and more.

During the actual existence of observed SMEs in $57 \%$ cases the number of export destinations was increasing. Conversely, $38 \%$ of companies experienced constant development and $5 \%$ decreasing tendency.

The most frequent reason for the entering foreign markets are proximity of the foreign markets $(54,58$ $\%)$, size of the foreign market $(53,82 \%)$ and increasing use of own capacities $(43,13 \%)$.

Other question was directed at the perceived difference between cultural and social environment in domestic and foreign market. As a Fig. 1 shows, most companies (55\%) do not consider that cultural and social differences are an important factor. It is a very important factor for $10 \%$ and moderately important for $29 \%$. The rest (6\%) said they do not know. This perception can cause problems especially when trying to adopt a product or a communication adaptation strategy.

Fig. 1: Perception of cultural differences between domestic and export market by companies sampled

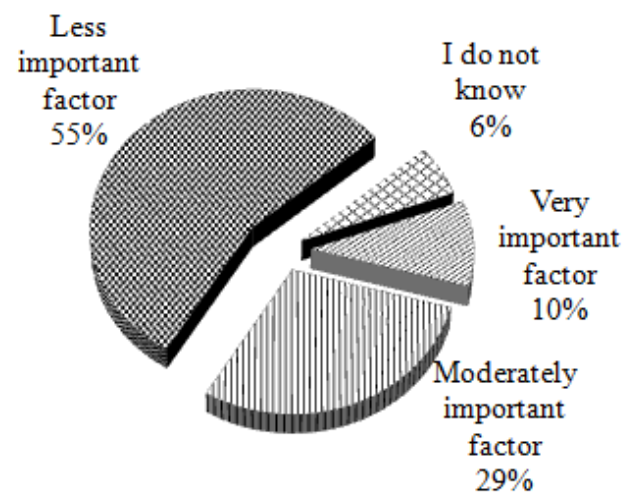

Sources: own research

Another point of interest was marketing research since it provides important information for managerôs strategic decisions. Despite this fact $51 \%$ of SMEs do not conduct international marketing research at any form. At least, $41 \%$ sampled companies do research on selected foreign markets and 8 $\%$ do all market research.

Fig. 2: Marketing research approaches on foreign markets

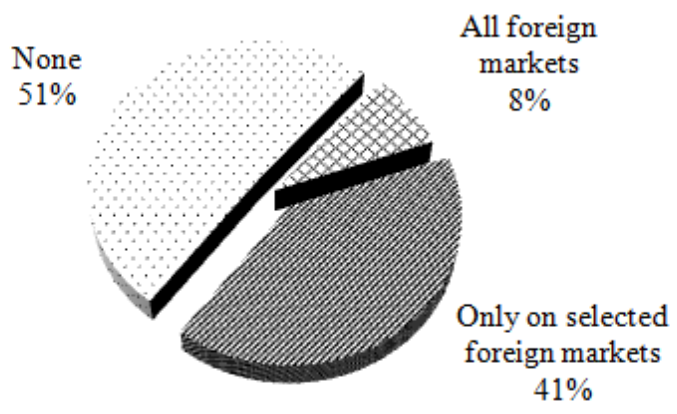

Sources: own research

It can be assumed that for SMEs, it is difficult from financial, personnel and time perspective to perform own marketing research or maintain marketing information system. Despites this fact, companies drawn information from various sources. Unfortunately, informational support from Czech 
bureaus, institutions and agencies is at the bottom of the list. This finding raises doubts about the effectiveness of these institutions.

\section{Product, distribution and marketing communications}

In the area of product strategy, Fig. 3 shows that most respondents use the sale products on foreign markets in a form in which it is offered in the domestic market - standardization (62.94\%).

Standardization may secure a better market results for SMEs through lower costs and therefore gain global competitiveness. Significantly fewer respondents $(24.05 \%)$ reported that they adapt domestic production due to the specific conditions in the foreign market. 13,01\% of companies develop a new product

In the area of distribution strategy forms, direct distribution (50.76\%) prevails. Thus, company trades through its own dealers or export department. Indirect distribution is typical for $19,08 \%$ subjects and combination for $30,15 \%$.

The largest share of the companies export is in B2B (business-to-business) sector (40\%). This finding is consistent with sample characteristics, where companies from machinery industry dominate. B2C (business-to-customer) sector where products are sold for final consumption is less represented in the sample in $30 \%$. Eventually, the combination of B2B and B2C is represented in $30 \%$ of businesses.

Excluding companies operating in both markets the Pearson chi-square test was used to figure out whether and which marketing communication tools were used by the theoretical assumptions for different business environment. Practically, which variables of marketing communication were significantly associated with the market type.

Clearly, personal selling is recommended to use more on B2B markets while advertising is dominant as a tool on B2C markets and so on. There is no statistically significant association in the data between the type of business and marketing communications used. Therefore it can be assumed, that there is a certain misuse of marketing communication mix among the SMEs sampled.

\section{Fig. 3: Standardization and adaptation of product on international markets}

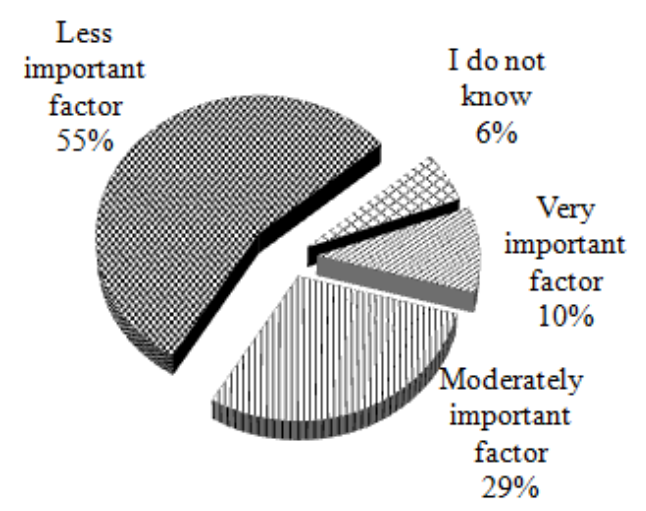

Sources: own research

\section{Conclusion}

Some of the findings could be expected $\ddot{i}$ such as that the firms export their production to the nearest neighborôs states: Slovakia and Poland. Another fact which could be predicted is that firms use the electronic media (Internet) to present their products and to communicate with their B2B or B2C customers. Some of the outcomes point out interesting trends $i ̈$ for example quite low utilization of the potential of different forms of support and assistance (advice) from the governmental and non- 
governmental institutions. The reasons for this may be the administrative barriers for obtaining various grants, that small and medium-sized companies are not aware of these possibilities and even the general focus of these projects, which could be better adapted to specific types of businesses in certain areas of activity.

The fact that firms mostly do not accept different cultural and social conditions at foreign markets could be evaluated also negatively. At the same time, most respondents apply strategy of standardization to foreign markets. Of course this depends on the type of exported product, the destination and the target group of customers (consumer market versus industrial market). Since the biggest part of the output of the addressed companies is bound for Slovak market, it is expected that market conditions are relatively uniform with the domestic market. Striking, however, is that in general, companies see this issue as just a minor on e, and this is not compatible with developing their own competitiveness on foreign markets.

From the marketing point of view it is positive that for small and medium businesses it is crucial to focus on the needs and wishes of customers. The small firms carry out innumerable little innovations thanks to their fast adaptation towards the needs of the customer. Small and medium companies are also able to function at the peripheral areas of the market which are not so attractive for larger companies. On the other hand they do not pay enough attention to acquiring information about foreign markets which may be existentially decisive for them. More than half of the surveyed firms do not implement marketing research. It is likely that the main reasons are lack of finances and lack of own skilled workers who are able to secure marketing survey. It would be profitable to pay more attention to this field and make sure to investigate the market from time to time. This could be done by cooperation on the research activities with external agency or by using different forms of research support from governmental and non-governmental institutions.

\section{References}

[1] Czech statistical office., (2013). Small and medium enterprises in Czech economy in the years 2003-2010.

[2] HYNES, B., (2010). International Small Business Growth: A Process Perspective. Irish Journal of Management, vol. 29, iss.2, pp. 87-106.

[3] KAZEM, A., VAN DER HEIJDEN, B., (2006). Exporting Firms' Strategic Choices: The Case of Egyptian SMEs in the Food Industry. SAM Advanced Management Journal, vol. 71, iss.3, pp. 21-33.

[4] KNIGHT, G. A., (2001). Entrepreneurship and Strategy in the International SME. Journal of International Management, ò vol.7, iss. 3, pp. 155-171. DOI 10.1016/S1075-4253(01)00042-4.

[5] KOTLER, P., KELLER, K. L., (2012). A Framework for Marketing Management. Harlow: Pearson Education Limited. p. 310.

[6] LU, J.W., BEAMISH, P.W., (2001). The Internationalization and Performance of SMEs. Strategic Management Journal, vol. 22, iss. 6/7, pp. 565ï 586. DOI 10.1002/smj.184.

[7] MACHKOVÁ, H., KRÁL, P., M. LHOTÁKOVÁ, M., (2010). International marketing. Praha: Oeconomica.

[8] MASON, M. C., PAUluZZO, R., (2009). SMEs: The Path Towards International Success. Oxford Journal, vol.8, iss.1, pp. 151-167.

[9] ONKVISIT, S., SHAW, J. J., (2004). International marketing: analysis and strategy. New York: Routledge.

[10] STOKLASA, M., STARZYCZNÁ, H., MATUǴNSKÁ, K., (2013). Czech food and regional brands within the globalized market. Advanced Social Science Letter. Miramar, USA.

[11] SZYMANSKI, D., BHARADWAJ, S., VARADARAJAN, P. R., (1993). Standardization versus adaptation of international marketing strategy: an empirical investigation. Journal of Marketing, vol.57, iss.2, pp. 1-17. DOI 10.2307/1252215.

[12] WELCH, L. S., LUOSTARINEN, R. K., (1988). Internationalization: Evolution of a Concept. Journal of General Management, vol. 14, iss. 2, pp. 36-64.

This paper is one of the research outputs of EU project CZ.1.07/2.3.00/20.0016 òThrough the targeted research in the area of small and middle-sized companies to reaching competitive knowledge economyò 